\title{
Play Activities for Primary English Learners in Vietnam
}

\author{
Le Pham Hoai Huong \\ Hue University, Vietnam
}

\begin{abstract}
This article discusses the play activities that are used in primary English classes in a city in Vietnam. Video recording the classes and interviewing the teachers show that various play activities, for example, bingo, miming, hangman, and TPR (Total Physical Response) activities were employed in these classes. Through the play activities, students practiced vocabulary, simple grammatical structures, and language skills such as listening and speaking. In addition, the students learned to follow game rules, support team members, and lead when necessary. Based on the practical values of play activities, the paper provides suggestions on how to use specific play activities in primary English classes, the language skills / areas to be targeted at with play activities, and how to manage the play activities.
\end{abstract}

\section{The Importance of Play in Learning}

Play in learning at the primary level. The definitions of play vary, but the emphasis always includes the fun that play brings to young learners. Play is anything done in a playful manner, as play is a "communication style" (Beresin 1993, p. 252). Play includes learning games and games promoting physical play. In this sense, learning is a precondition for and an integrated part of children's play activities (Sorensen \& Meyer, 2007). Play promotes learners' active involvement and engagement, both verbally and non-verbally, with materials, peers, and the learning environment (Shipley, 2008). The British Council (2007) pointed out that at primaryschool age, students do not realize of the importance of learning; therefore, teachers should know how to combine learning and playing in group and pair activities to create excitement. In other words, play motivates learners to learn (Cook, 1997; Shipley, 2008), even when learners become frustrated due to losing a competition.

Play is also considered as experiential learning (Verenikina, Harris, \& Lysaght, 2003); when children participate in play activities, they subconsciously self-reflect and develop abstract thinking as well as social communication skills. In play activities, children learn and have to abide by rules but also feel free to express their emotions. According to Bodrova and Leong (2001), play provides a unique context where children can develop the ability to self-regulate their behavior at the highest attainable level.

Sociocultural theorists view play as a vital activity of the early childhood years (Vygotsky, 1978). For Vygotskians, play can be imaginary situations and activities with roles and rules.

Language Education in Asia, 2013, 4(1), 76-87.http://dx.doi.org/10.5746/LEiA/13/V4/I1/A6/Le 
The former are usually explicit, but the latter are typically implicit. Children are expected to know the general rules and roles in play activities (Bodrova \& Leong, 2001).

Play in language learning. Play activities are described in different ways in language learning. They can be small-group discussions, games, and skits in which the creative and playful use of language is facilitated (Pomerantz \& Bell, 2007). They can also use music, games, and TPR (Total Physical Response) activities, verbal play, vocabulary building, talking to oneself in the classroom, or even creating "crazy" sentences such as, "The octopus ate the giant purple banana" (Bacha, 2011, Play section, para. 3).

There are various reasons to use play in language learning. Play provides a rich, complex environment for learning with both form-focused and meaning-focused activities (Cook, 1997). Play includes types of games which are beneficial in many ways both for learning and the emotions of learners (Gee, 2008). In Gee's (2008) point of view, play promotes sharing knowledge, collaboration, and problem solving; players become the owners of their actions and language and can situate meanings of words from actions, images, interaction, and the participation of others.

Discussing play in more detail, Cook (2000) has said that play in language learning is classified into two groups: patterned sound and pragmatic contextualized meaning. The first group contains verse, speech, and semantic meaning, while the second shows the interaction between interlocutors. Pomerantz and Bell (2007) argued that language play is necessary for language production in EFL classrooms. Instances of spontaneous, creative language play help learners practice various vocabulary and sentence structures. In addition, humorous moments in play provide opportunities for participants to use language, contributing to the growth of learners' communicative ability in general. Language play is fun and commonly marked overtly by laughter or other signs of enjoyment. In classrooms where play with language happens, class members develop a sense of community and construct a play frame around utterances or interactions (Sullivan, 2000).

In this study, a play activity refers to the actions and language used in learning English by young learners. It could be each member in the class using words to make a sentence when it is his / her turn to do this in competition with another member, acting out a song, or calling out a word starting with a letter of the alphabet. In these play activities, students usually have fun learning simple words and grammar structures or practicing language skills.

\section{Primary English in Vietnam}

English at the primary level in Vietnam has been neglected for years, although English has gained popularity in this country since the Doi Moi (innovation) Policy in the 1980 s. According to the Vietnam's Ministry of Education and Training (2010), Vietnam has a high demand for teachers of English for primary schools (the ministry claims that by 2020 all Grade 3 students will have to study English). However, at present, only a few pedagogical junior colleges and universities in Vietnam offer courses to train English teachers at the primary level. As a result, Vietnam severely lacks primary English teachers (Minh, 2011; Tran \& Tran, 2011). Nguyen (2011) revealed that some private schools in the larger cities in Vietnam have started to offer English courses for Grade 1 learners for as many as 12 periods per week; however, the practice of teaching and learning English at the primary level varies across the regions of the country. 
Recently, the Ministry of Education and Training launched a project for the period up to 2020 (Vietnamese Ministry of Education and Training, 2010) to improve the competence of primary English teachers and so promote the effectiveness of learning in young learners. In 2010, a pilot English primary program was implemented with four 40-minute periods per week starting from Grade 3 (Nguyen, 2011). In the city where this study was carried out, students learn English from Grade 1 to Grade 5, and the number of periods for English ranges from 2 periods to 4. Each school has certain English textbooks for primary English learners, published either abroad or in Vietnam. Apart from learning English at school, students can go to English language centers for extra English lessons. Learning at the centers focuses on topics similar to those taught in primary schools.

\section{The Study}

Given that primary English in Vietnam is highly important but neglected, and that play has an influential role in English learning, it is worth investigating how play, specifically, physical games, language games, and verbal language play, is used in primary English classrooms in an area of Vietnam and which language skills or areas are targeted. The research questions of this study are thus:

1. How are play activities employed in primary English classes in Vietnam?

2. What do learners practice with these play activities?

\section{Participants}

To collect data, 11 groups of primary English learners at an English language center in Vietnam and 11 teachers teaching at the center were invited to take part in the study. The number of students in each class varied from 8 to 20. The students who came to the English center were from Grade 1 to Grade 6 in various primary schools in a city in Vietnam. They studied twice a week, and they had been studying at this center for periods ranging from about 2 months to 2 years. The teachers had graduated from university with a bachelor's degree in English, specializing in English pedagogy or interpretation. One teacher has a master's degree in TESOL. They had been teaching English at the primary level for at least 3 months. Some had up to two years of experience of teaching at this level. The teachers are all female, and about $65 \%$ of their students are also female.

\section{Data Collection}

Video recording and interviews were the two main data collection tools. The researcher recorded the activities in which the teachers facilitated learners' play (e.g., games, TPR activities, language play with sounds and vocabulary). Recording was conducted for a period of 2 weeks. Six teachers out of the 11 working at the center, teaching a total of 11 classes, were recorded. Only play activities were recorded for data analysis. Each recording lasted from 5 to 19 minutes. The researcher asked for consent from the classroom teachers to video record the classes and arranged with the classroom teachers when to do the recording to ensure that the normal classroom process was not altered. The play activities were part of the teaching and learning in these classes. They were not set up for research purposes.

Interviews with the six participant teachers who taught the 11 classes mentioned above were conducted after the video recordings. The interviews were in English and, when necessary, in Vietnamese to ensure a smooth flow of ideas. Any Vietnamese language used was translated into English by the researcher. Each interview lasted about 10 minutes and was conducted at the teacher's convenience. The interviews were facilitated with interview questions prepared in English (Appendix A). The play activities listed in the interview questions came from a teacher- 
training guide for motivating learning from the British Council (2009). When all data were collected, the researcher viewed the video recordings and described the play activities seen. All the video descriptions were compiled according to classes and dated (see Appendix B for a sample video recording description).

\section{Play Activities in Primary English Classes}

\section{Findings and Discussion}

Although play is a common activity in primary classes because of its many benefits (Cook, 1997; Shipley, 2008; Sorensen \& Meyer, 2007), there is no fixed recipe for how frequently teachers should employ play in the classroom. The type and frequency of the play activities reported by the interviewed teachers are presented in Table 1.

Table 1

Play Activities Reported by Primary English Teachers

\begin{tabular}{|c|c|}
\hline Play activities & $\begin{array}{l}\text { Number of } \\
\text { times used } \\
\text { during the data } \\
\text { collection } \\
\text { period }\end{array}$ \\
\hline Bingo & 10 \\
\hline Miming & 10 \\
\hline TPR activities & 10 \\
\hline Vocabulary building & 10 \\
\hline Hangman & 10 \\
\hline Slap the board & 9 \\
\hline Whispers & 8 \\
\hline Guessing & 8 \\
\hline Shark attack & 8 \\
\hline Hot seat & 7 \\
\hline Number grab & 6 \\
\hline Acting out a song & 6 \\
\hline Feely bag game & 5 \\
\hline Pretend game & 5 \\
\hline Creating "crazy" sentences & 4 \\
\hline What's missing? & 3 \\
\hline What number is it? & 1 \\
\hline
\end{tabular}

The first four kinds of play activities, bingo, miming, TPR activities, and vocabulary building, were reported to be used by nearly all the interviewed teachers. This could be because these activities are common and easy to apply in primary classrooms. The teachers could also have been familiar with them or trained to use them. Moreover, these activities do not require much preparation by teachers. For example, teachers can at any time during their class ask students to search for words from a piece of paper and call out "bingo" when they have found all the words or just to mime an action without using language. 
When interviewed, the teachers also said that they employed other play activities not mentioned in the list. For example, Teacher A pointed out that she used various musical toys to help students have fun. Her class occasionally also made animal sounds, listed words by groups, and played a dice game. Teacher B said she asked her students to make up songs with words, make a song from sentences, and draw pictures from words she gave them. Teacher $C$ said her class enjoyed dice games, crosswords, and noughts and crosses. Teacher D used games on the computer, especially Who Wants to Be a Millionaire? Teacher E reported that she asked her students to retell the words written on pieces of paper in a box and used ball passing to play with vocabulary. Teacher F described the use of a dice game and "Simon Says." Teacher F also asked her students to create funny portraits and play crosswords. In the interviews, the teachers said that play activities came from university and graduate courses, colleagues, classmates, and the Internet, or were made by themselves. Overall, the interviews and video recordings indicated the teachers' creativity in teaching young learners.

When asked how often they used play activities in their classes, all of the teachers said they used them in every lesson and at different stages. Two added that they used play activities to cheer students up when the classroom atmosphere seemed tired. Two others reported they often used play activities as warm-ups. One emphasized that she considered students' levels and attitudes to choose play activities for her class. To manage play activities, all the teachers interviewed remarked that they involved the whole class in play activities for the warm-up stage. Four added that they had play activities in the warm-up and production stages. Two teachers said they had play activities in the practice stage.

The video recordings of 11 classes show that all the play activities started with instructions mainly in Vietnamese. Few teachers used English alone to explain what students needed to pay attention to. Teachers sometimes provided models involving students. In summary, play activities were used in all lessons, with patterns varying according to teachers' preferences. The activities were executed with instructions, rules, and models.

\section{Skills / Language Areas Practiced in Play Activities}

The 11 video recordings were viewed and the observed play described in categories: play activities, language practice, language skills, and other skills involved in the play activities. Table 2 presents a summary of the recordings. 
Table 2

Play Activities and Targeted Language Skills / Areas

\begin{tabular}{|c|c|c|c|c|}
\hline Play activity & Description & $\begin{array}{l}\text { Language } \\
\text { Practice }\end{array}$ & $\begin{array}{l}\text { Language } \\
\text { Skills }\end{array}$ & Other Skills \\
\hline Hot seat & $\begin{array}{l}\text { Two chairs were put in } \\
\text { front of the class and } \\
\text { labeled with "Animals" } \\
\text { and "In the classroom." } \\
\text { Students had to sit in the } \\
\text { correct chair. }\end{array}$ & $\begin{array}{l}\text { Reviewing } \\
\text { vocabulary } \\
\text { related to } \\
\text { animals and } \\
\text { items in the } \\
\text { classroom }\end{array}$ & $\begin{array}{l}\text { Listening, } \\
\text { pronouncing }\end{array}$ & $\begin{array}{l}\text { Competing to sit on } \\
\text { the "hot seat" faster } \\
\text { Cheering and } \\
\text { supporting team } \\
\text { members }\end{array}$ \\
\hline $\begin{array}{l}\text { Bear } \\
\text { grabbing }\end{array}$ & $\begin{array}{l}\text { Students asked and } \\
\text { answered questions and } \\
\text { grabbed the bear. }\end{array}$ & $\begin{array}{l}\text { Practicing the } \\
\text { question "How } \\
\text { many?" and } \\
\text { simple words to } \\
\text { be used with } \\
\text { "How many?" }\end{array}$ & $\begin{array}{l}\text { Listening and } \\
\text { speaking }\end{array}$ & $\begin{array}{l}\text { Turn taking and } \\
\text { being alert in giving } \\
\text { correct answers }\end{array}$ \\
\hline $\begin{array}{l}\text { Ball passing } \\
\text { with } \\
\text { vocabulary }\end{array}$ & $\begin{array}{l}\text { Students passed the ball. } \\
\text { The student who received } \\
\text { the ball had to make a } \\
\text { word starting with a letter } \\
\text { of the alphabet. }\end{array}$ & $\begin{array}{l}\text { Reviewing } \\
\text { vocabulary of a } \\
\text { wide range }\end{array}$ & $\begin{array}{l}\text { Listening and } \\
\text { pronouncing } \\
\text { words }\end{array}$ & $\begin{array}{l}\text { Waiting for turns, } \\
\text { being prompt in } \\
\text { doing an action }\end{array}$ \\
\hline Bicycle race & $\begin{array}{l}\text { Students played with } \\
\text { words. For example, one } \\
\text { student wrote sun, and } \\
\text { another used the last } \\
\text { letter in sun to make a } \\
\text { new word starting with } n \text { : } \\
\text { night. }\end{array}$ & $\begin{array}{l}\text { Reviewing a } \\
\text { wide range of } \\
\text { vocabulary }\end{array}$ & $\begin{array}{l}\text { Writing and } \\
\text { spelling words }\end{array}$ & $\begin{array}{l}\text { Judging if the words } \\
\text { written by the other } \\
\text { team members were } \\
\text { correct } \\
\text { Supporting team } \\
\text { members }\end{array}$ \\
\hline $\begin{array}{l}\text { TPR } \\
\text { activities }\end{array}$ & $\begin{array}{l}\text { Students performed } \\
\text { actions according to the } \\
\text { imperatives or commands } \\
\text { of the teacher. Students } \\
\text { responded to simple } \\
\text { imperatives from the } \\
\text { teacher and the CD. }\end{array}$ & $\begin{array}{l}\text { Reviewing } \\
\text { simple } \\
\text { imperatives such } \\
\text { as "stand up," } \\
\text { "sit down," and } \\
\text { "clap your } \\
\text { hands" }\end{array}$ & $\begin{array}{l}\text { Listening } \\
\text { comprehen- } \\
\text { sion. }\end{array}$ & $\begin{array}{l}\text { Accepting fun } \\
\text { punishment for not } \\
\text { responding correctly } \\
\text { to the teacher's } \\
\text { commands } \\
\text { Doing physical } \\
\text { movements }\end{array}$ \\
\hline $\begin{array}{l}\text { Flower } \\
\text { drawing }\end{array}$ & $\begin{array}{l}\text { Students competed to } \\
\text { draw petals for their } \\
\text { group's flower. If they } \\
\text { said the words correctly } \\
\text { their team would have } \\
\text { one petal for their flower. }\end{array}$ & $\begin{array}{l}\text { Reviewing words } \\
\text { related to } \\
\text { classroom items }\end{array}$ & $\begin{array}{l}\text { Writing and } \\
\text { spelling words }\end{array}$ & $\begin{array}{l}\text { Supporting their } \\
\text { team members }\end{array}$ \\
\hline Hangman & $\begin{array}{l}\text { Students worked in two } \\
\text { teams to spell correct } \\
\text { words with hints from the } \\
\text { teacher. If they could not } \\
\text { spell correctly, their } \\
\text { hangman picture would } \\
\text { have more strokes, } \\
\text { denoting losing the game }\end{array}$ & $\begin{array}{l}\text { Reviewing words } \\
\text { related to } \\
\text { animals, e.g., } \\
\text { grasshopper and } \\
\text { dragonfly }\end{array}$ & $\begin{array}{l}\text { Spelling } \\
\text { words }\end{array}$ & $\begin{array}{l}\text { Competing to win } \\
\text { Supporting team } \\
\text { members }\end{array}$ \\
\hline
\end{tabular}




\begin{tabular}{|l|l|l|l|l|}
\hline $\begin{array}{l}\text { Keep and } \\
\text { take }\end{array}$ & $\begin{array}{l}\text { The class was divided into } \\
\text { two teams. Members of } \\
\text { each team took a turn on } \\
\text { the chair to ask and } \\
\text { answer a question and } \\
\text { grab the wool strawberry } \\
\text { to get scores for his / her } \\
\text { team. }\end{array}$ & $\begin{array}{l}\text { Practicing simple } \\
\text { questions and } \\
\text { answers such as } \\
\text { "How old are } \\
\text { you?", "What's } \\
\text { your name?", } \\
\text { "What's the } \\
\text { weather like?" }\end{array}$ & $\begin{array}{l}\text { Listening } \\
\text { comprehen- } \\
\text { sion }\end{array}$ & Turn taking \\
\hline Dice game & $\begin{array}{l}\text { Board game with dice: } \\
\text { Students from the two } \\
\text { teams did actions } \\
\text { according to the teacher's } \\
\text { commands. }\end{array}$ & $\begin{array}{l}\text { Reviewing a } \\
\text { wide range of } \\
\text { vocabulary }\end{array}$ & $\begin{array}{l}\text { Listening } \\
\text { comprehen- } \\
\text { sion. }\end{array}$ & $\begin{array}{l}\text { Following game rules } \\
\text { Having prizes and } \\
\text { fun punishment in a } \\
\text { game }\end{array}$ \\
\hline $\begin{array}{l}\text { Object } \\
\text { passing } \\
\text { with music }\end{array}$ & $\begin{array}{l}\text { The teacher played music } \\
\text { and students passed the } \\
\text { doll. When the teacher } \\
\text { paused the music at } \\
\text { different intervals, the } \\
\text { student who had the doll } \\
\text { had to do something as } \\
\text { asked by the teacher or } \\
\text { classmates. }\end{array}$ & $\begin{array}{l}\text { Asking and } \\
\text { answering } \\
\text { questions from } \\
\text { the teacher and } \\
\text { other students in } \\
\text { the class }\end{array}$ & $\begin{array}{l}\text { English } \\
\text { chants }\end{array}$ & $\begin{array}{l}\text { Being alert to } \\
\text { promptly do the } \\
\text { action as required }\end{array}$ \\
\hline
\end{tabular}

The video recordings show that by participating in play activities, the students reviewed vocabulary, spelling, and pronunciation, and practiced listening and speaking skills as well. On the social level, they demonstrated team spirit and competition, and also abided by rules.

\section{Why Teachers Used Play}

In the interviews, the teachers gave different opinions about why they used play activities in their classes. All the teachers agreed that students had fun with play activities, which stimulated and motivated them. The teachers also pointed out that students learned and remembered words and simple sentence structures longer. Teacher D said, "Play activities help students remember words used in the play activities, love teachers more, and have more rapport with the teacher." Similarly, Teacher F added, "Play activities create a relaxing learning atmosphere and build confidence and team spirits." Play activities also gave students practice in speaking and presenting skills as well as pronunciation (Teachers A and B). Teacher C elaborated, "In play activities, students learn imperatives and remember lessons longer. Furthermore, shy students are encouraged in play activities." Teachers B and F remarked, "Students practice speaking at the basic level and learn social skills such as group work, leadership skills, and competition." Reflecting a broader sense, Teacher D noted, "In play, students also learn cultures and festivals of English speaking countries, which stimulate curiosity and interest of students in learning English."

\section{Conclusion}

Play in teaching young learners is highly recommended, especially in language learning and teaching for learning form and meaning (Cook, 1997) and for enhancing the emotions, shared intelligence, and collaborative skills of learners (Gee, 2008). The current study shows that students had fun playing and reviewing and remembering words from previous lessons. They learned to support each other and compete just for fun. All the students looked cheerful in the 
video recordings, perhaps because play activities do not create tension and challenge children to think beyond their level. They are just for fun and practice.

This paper reports the findings of a small-scale study which cannot be generalized; however, where contexts are similar, the following suggestions are offered regarding kinds of play activities to be employed and how to use them to target certain skills and language areas in primary English classes.

Classroom teachers can employ available games, such as hot seat, dice game, shark attack, and hangman, but vary the content to match specific lessons. Primary teachers may even make up play activities. They may also ask students to compete for an object, for example, a toy bear, a ball, or a flower. Such simple games will make the class a fun environment for learning. Play activities can be used as warm-ups, at the production stage, or at any other stage of the lesson, provided that they engage students in a learning task. The time for each play activity should vary from 5 to 15 minutes. In conducting a play activity, teachers need to give instructions, model the activity, and check students' understanding of the rules. In addition, encouraging competition between students in games by giving prizes and fun punishments (e.g., losers have to sing a song or skip around the classroom, as requested by the winners) will make students more excited.

At the primary level, students taking part in play activities practice listening, speaking, and writing skills. They seldom read when playing, but they review vocabulary and grammatical structures. The students could have learned these language areas and skills in previous lessons, or they could learn these new skills from participating and observing other students. Either way, the students reinforce or practice targeted skills.

The study focused on the play activities at an English center and explored how they were employed and for what purposes. It did not go as far as looking at each transcript to compare the language used by young learners to make recommendations concerning various learning opportunities which different types of play activities can offer. Perhaps a future study is needed to investigate what, in specific terms of language, primary students learn through play activities. Such a study would need to take place over a longer period of time, recording students in several play activities.

Play not only stimulates the learning process but also makes teaching less daunting. With play activities, teachers adopt a different role. They, to some extent, move away from the traditional image of a teacher just giving knowledge, because they have created a fun way for students to learn through mental and physical involvement. In this process, teachers become participants and organizers. Therefore, to meet the need of young learners to learn in a relaxing atmosphere, teachers should have a collection of games and use them flexibly. For primary teachers to be equipped with knowledge about play and how to use it effectively, it is important that they seek out activities and, even more importantly, are trained systematically in their courses at college or university on how to use games and other play activities. 


\section{Author Note}

Le Pham Hoai Huong, English Department, College of Foreign Languages, Hue University, Hue, Vietnam.

I would like to thank the CamTESOL research grant for giving the opportunity to carry out the study. I thank Dr. Geraldine McDonald, Honorary Research Fellow, Victoria University of Wellington, New Zealand for suggestions on the early drafts of the paper. I also would like to thank Dr. Alan Klein, University of British Columbia, Canada, for his advice on the paper.

Correspondence concerning this article should be addressed to Le Pham Hoai Huong, 293 Nguyen Trai, Tay Loc-Hue, Vietnam. E-mail: quangandhuong@gmail.com 


\section{References}

Bacha, J. (2011). Play and affect in language learning. Retrieved from: http://genkienglish.net/playandaffect.htm

Beresin, A. R. (1993). The play of peer cultures in a city school yard: "Reeling," "writhing," and "a rhythmic kick."(Unpublished doctoral dissertation). University of Pennsylvania, Philadelphia, PA.

Bodrova, E., \& Leong, D. (2001). Tools of the mind: A case study of implementing the Vygotskian approach in American early childhood and primary classrooms. (Innodata Monographs -7). Switzerland: UNESCO International Bureau of Education.

British Council. (2007). Primary innovations: A collection of papers. Hanoi, Vietnam.

British Council. (2009). Motivating learning: Approaches and activities that bring English to life in the primary classroom. Bangkok, Thailand.

Cook, G. (1997). Language play, language learning. ELT Journal, 51(3), 224-231. http://dx.doi.org/10.1093/elt/51.3.224

Cook, G. (2000). Language play, language learning. New York, NY: Oxford University Press.

Gee, J. P. (2008). Learning and games. In K. Salen (Ed.), The ecology of games: Connecting youth, games and learning (pp. 21-40). Cambridge, MA: The MIT Press.

Minh, C. (2011). Primary schools lack English teachers. Vietnamese News. Retrieved from: http://vietnamnews.vnagency.com.vn/Talk-Around-Town/218590/primary-schools-lackenglish-teachers.html

Nguyen, T. M. H. (2011). Primary English language education policy in Vietnam: Insights from implementation. Current Issues in Language Planning, 12(2), 225-249. http://dx.doi.org/10.1080/14664208.2011.597048

Pomerantz, A., \& Bell, N. (2007). Learning to play, playing to learn: FL learners as multicompetent language users. Applied Linguistics, 28(4), 556-578. http://dx.doi.org/10.1093/applin/amm044

Shipley, D. (2008). Empowering children. Play based curriculum for lifelong learning. Scarborough, Canada: Nelson Education.

Sorensen, B. H., \& Meyer, B. (2007). Serious Games in language learning and teaching - A theoretical perspective. In A. Baba (Ed.), Proceedings of DiGRA 2007 Conference: Situated Play. Available at http://www.digra.org/wp-content/uploads/digitallibrary/07312.23426.pdf

Sullivan, P. (2000). Playfulness as mediation in communicative language teaching in a Vietnamese classroom. In J. P. Lantolf (Ed.), Sociocultural theory and second language learning (pp.115-131). Oxford, England: Oxford University Press.

Tran, H. L., \& Tran, L. A. (2011). Teaching primary English in Vietnam: A theoretical framework. Research paper from Hanoi National University, Vietnam. Retrieved from http://hdl.handle.net/123456789/600

Verenikina, I., Harris, P., \& Lysaght, P. (2003, July). Child's play: Computer games, theories of play and children's development. Paper presented at the Young Children and Learning Technologies Conference, UWS, Parramatta, Australia.

Vietnamese Ministry of Education and Training (2010). Draft of primary English program: Project of the year 2020. Retrieved from http://www.moet.gov.vn/?page=1.24\&view=2545

Vygotsky, L. (1978). Mind in society. Cambridge, MA: Harvard University Press. 


\section{Appendix A}

\section{Questions for Interviews With Primary English Teachers}

\begin{tabular}{|l|l|}
\hline Please tell me if you use the following play activities in your class & Yes \\
\hline Bingo: Students find the words/pictures according to instructions. & \\
\hline $\begin{array}{l}\text { What number is it? For example, children stick a number on a child's back and } \\
\text { ask the question "What number is it?" The class repeats the expression and } \\
\text { answer to practice vocabulary for numbers and pronouncing them. }\end{array}$ & \\
\hline $\begin{array}{l}\text { Whispers: Students whisper the questions to practice chunks of language "What's } \\
\text { your favorite sport?", "Why do you like it?" Students whisper from a student at } \\
\text { the last row of the class to a student in the first row who will write the whispered } \\
\text { sentence on the board. }\end{array}$ & \\
\hline What's missing? Learners find the missing pictures in a story. & \\
\hline $\begin{array}{l}\text { Number grab: The teacher says a word "a pencil" and the children have to grab } \\
\text { the right picture. }\end{array}$ & \\
\hline Mime game: Learners mime the actions. & \\
\hline Guessing game: Learners guess words from pictures. & \\
\hline $\begin{array}{l}\text { Feely bag game: Learners describe objects in a bag and others have to say the } \\
\text { words. }\end{array}$ & \\
\hline $\begin{array}{l}\text { TPR activities: Learners do actions according to imperatives given by teachers or } \\
\text { other classmates. }\end{array}$ & \\
\hline Creating "crazy" sentences, such as, "The octopus ate the giant purple banana." & \\
\hline $\begin{array}{l}\text { Acting out a song: For example, for the song "Five little ducks," learners act as } \\
\text { the little ducks and a mother duck and sing along the song. }\end{array}$ & \\
\hline Pretend game: Learners act the role of somebody else and pretend. & \\
\hline Vocabulary building & \\
\hline Hot seat & \\
\hline Slap the board & \\
\hline Hangman & \\
\hline Shark attack & \\
\hline Others? Please specify & \\
\hline
\end{tabular}

1. How often do you have play activities in your class?

2. Do you involve the whole class or just some volunteers in play activities?

3. At which stage of a lesson do you use play activities?

4. Where do you get ideas for play activities from?

5. How do you manage play activities?

6. How do you think learners benefit from play activities? 


\section{Appendix B \\ Sample of Video Recording Description}

Video Recording 1. Date: 24 June 2012

The class has 18 students. They were in Grades 3-5 at primary schools. The play activity was carried out near the end of a 90-minute class. The teacher organized the "hot seat" activity. She put two chairs in the front of the class of a $U$ shape. The teacher explained to the students how to participate in the game. The students joined enthusiastically and noisily. The students stood in two lines. The two chairs were labeled "Animals" and "In the classroom." The teacher read out loud one word, for example, "crayon," then two students in front of each line would run quickly to sit in the right chair. In this case, the student who was faster to run to sit on the chair labeled "In the classroom" would win one point for his team. If the student sat on the wrong chair, no point was recorded. The activity ended when the teachers finished using the cards to call out the words for both teams.

The students practiced listening skills when they paid attention to the teacher reading the words out loud. They also had the opportunity to recall the vocabulary related to their previous lessons: animals and items in the classroom. At the social level, the students learned how to compete with other team members to be faster to sit on the hot seat. They cooperated in yelling and cheering their team members to win. 